\title{
Hijama in islam
}

Umuruddeen Auwal

Potential competing interests: The author(s) declared that no potential competing interests exist.

Wet Cupping (Hijama) is one of the remedies from the sunnah of the Prophet Muhammad (sallallahu alaihi wasallam). Not only did he have hijama performed on himself, but he also recommended it as a beneficial treatment for various ailments 